\title{
The Thermal Stability of the Collagen Triple Helix Is Tuned According to the Environmental Temperature
}

\author{
Kazunori K. Fujii ${ }^{1}$, Yuki Taga ${ }^{2} \odot$, Yusuke K. Takagi ${ }^{1}$, Ryo Masuda ${ }^{3}$, Shunji Hattori ${ }^{2}$ and Takaki Koide ${ }^{1,3, *(1)}$ \\ 1 Department of Chemistry and Biochemistry, School of Advanced Science and Engineering, Waseda University, \\ Shinjuku, Tokyo 169-8555, Japan; k.fujii@ruri.waseda.jp (K.K.F.); takagi.yt@moegi.waseda.jp (Y.K.T.) \\ 2 Nippi Research Institute of Biomatrix, 520-11 Kuwabara, Toride 302-0017, Japan; y-taga@nippi-inc.co.jp (Y.T.); \\ shunhatt@nippi-inc.co.jp (S.H.) \\ 3 Waseda Research Institute for Science and Engineering, Waseda University, Shinjuku, Tokyo 169-8555, Japan; \\ r.masuda@aoni.waseda.jp \\ * Correspondence: koi@waseda.jp; Tel.: +81-3-5286-2569
}

Citation: Fujii, K.K.; Taga, Y.; Takagi, Y.K.; Masuda, R.; Hattori, S.; Koide, T. The Thermal Stability of the Collagen Triple Helix Is Tuned According to the Environmental Temperature. Int. J. Mol. Sci. 2022, 23, 2040. https://doi.org/10.3390/ ijms23042040

Academic Editor: Frank Zaucke

Received: 6 January 2022

Accepted: 10 February 2022

Published: 12 February 2022

Publisher's Note: MDPI stays neutral with regard to jurisdictional claims in published maps and institutional affiliations.

Copyright: (C) 2022 by the authors. Licensee MDPI, Basel, Switzerland. This article is an open access article distributed under the terms and conditions of the Creative Commons Attribution (CC BY) license (https:// creativecommons.org/licenses/by/ $4.0 /)$.

\begin{abstract}
Triple helix formation of procollagen occurs in the endoplasmic reticulum (ER) where the single-stranded $\alpha$-chains of procollagen undergo extensive post-translational modifications. The modifications include prolyl 4- and 3-hydroxylations, lysyl hydroxylation, and following glycosylations. The modifications, especially prolyl 4-hydroxylation, enhance the thermal stability of the procollagen triple helix. Procollagen molecules are transported to the Golgi and secreted from the cell, after the triple helix is formed in the ER. In this study, we investigated the relationship between the thermal stability of the collagen triple helix and environmental temperature. We analyzed the number of collagen post-translational modifications and thermal melting temperature and $\alpha$-chain composition of secreted type I collagen in zebrafish embryonic fibroblasts (ZF4) cultured at various temperatures $\left(18,23,28\right.$, and $\left.33^{\circ} \mathrm{C}\right)$. The results revealed that thermal stability and other properties of collagen were almost constant when ZF4 cells were cultured below $28{ }^{\circ} \mathrm{C}$. By contrast, at a higher temperature $\left(33^{\circ} \mathrm{C}\right)$, an increase in the number of post-translational modifications and a change in $\alpha$-chain composition of type I collagen were observed; hence, the collagen acquired higher thermal stability. The results indicate that the thermal stability of collagen could be autonomously tuned according to the environmental temperature in poikilotherms.
\end{abstract}

Keywords: collagen; triple helix; environmental temperature; post-translational modification; thermal stability

\section{Introduction}

Collagen is the most abundant protein in vertebrates. As the major component of the extracellular matrix, it plays roles not only in maintaining tissue structure but also in regulating cellular functions. A total of 28 types of collagen have been identified in humans [1]. Of these, type I collagen, the most abundant fibrillar collagen, has been well studied. Type I collagen has a triple-helical structure consisting of three polypeptide chains, called $\alpha$-chains, containing $>1000$ amino-acid residues. Each $\alpha$-chain contains more than 330 repeats of the Gly-X-Y triplet, with approximately one-third of positions $X$ and $Y$ occupied by proline (Pro) and 4-hydroxyproline (4-Hyp) residues, respectively.

The major post-translational modification of collagen, 4-hydroxylation of Pro, contributes significantly to the stabilization of the triple helix [2]. The number of 4-Hyp residues at position $\mathrm{Y}$ is positively correlated with the thermal denaturation temperature of the collagen triple helix [3-5]. Other collagen-specific post-translationally modified amino-acid residues include 3-Hyp at position $\mathrm{X}$ and hydroxylysine (Hyl) at position Y. Hyl residues are further glycosylated to form galactosyl-hydroxylysine or glucosyl-galactosyl-hydroxylysine residues. 3-Hyp was reported to enhance the thermal stability of the collagen triple helix [6]. However, no consensus on the effects of the lysine (Lys) side chain modifications exists [7,8]. 
The thermal stability of collagen in carp's scales collected in summer was $1.8^{\circ} \mathrm{C}$ higher than that obtained in winter [9]. Thus, the thermal stability of collagen in organisms grown at different environmental temperatures may vary within the same species or individuals.

The folding and post-translational modification of procollagen, a collagen precursor, occurs in the lumen of the endoplasmic reticulum (ER). The three pro $\alpha$-chains first associate at the C-propeptide domain and form a triple helix from C-to N-terminus [10,11]. Post-translational modifications are catalyzed by enzymes that recognize single-stranded polypeptides as their substrates [12]. Procollagen molecules with complete triple-helical domains are transported to the Golgi apparatus and then secreted into the extracellular space. Procollagen molecules that fail to form the triple helix are kept in or returned to the ER, and subsequently, degraded through autophagy [13].

HSP47, a procollagen-specific molecular chaperone in the ER of vertebrates, is constitutively expressed but is the only heat-shock protein found in the secretory pathway. The chaperone recognizes the triple-helical portions of procollagen in the lumen of the ER, thereby inhibiting the aggregation of procollagen [14] and/or stabilizing the triplehelical structure $[15,16]$. HSP47 dissociates in a pH-dependent manner in the cis-Golgi or ER-Golgi intermediate compartment and is then retrieved to the ER. The hsp47-knockout mice showed an embryonic lethal phenotype due to extensive collagen abnormalities, indicating that HSP47 is an essential chaperone at least in mammals [17]. In addition, various abnormalities have been observed in fibroblasts established from $h s p 47-$ knockout mice [14,17,18] and in cells obtained from dachshunds [19] and humans [20] with recessive mutations in the $h s p 47$ gene. They show accumulation of procollagen in the ER and excessive post-translational modifications of collagen.

Previously, we reported an increase in the number of post-translational modifications as well as in the thermal denaturation temperature and ratio of the $(\alpha 1)_{3}$ homotrimer of type I collagen secreted by $h s p 47-k n o c k o u t$ mouse fibroblasts [18]. Furthermore, the abnormalities observed at $37^{\circ} \mathrm{C}$ were rescued by incubating the cells at a lower temperature of $33^{\circ} \mathrm{C}$. These results indicated the essential function of HSP47 in stabilizing the triple-helical portions of procollagen, allowing for procollagen folding, which is not possible by the protein alone. Moreover, the properties of collagen, such as the number of post-translational modifications and thermal denaturation temperature of the triple helix, are affected by environmental temperature. However, there was little difference in the properties of collagen secreted from normal mouse fibroblasts cultured at 37 or $33^{\circ} \mathrm{C}$. In this study, by using poikilotherm cells, we tested the hypothesis that procollagen is post-translationally modified in the ER lumen until it forms a triple helix and acquires enough thermal stability to maintain the structure at the environmental temperature. Zebrafish are known to be tolerant to a wide range of temperatures $\left(10-40^{\circ} \mathrm{C}\right)$ [21,22]. Furthermore, zebrafish type I collagen has an $\alpha 3$-chain in addition to $\alpha 1$ - and $\alpha 2$-chains found in mammals. The $\alpha 3$-chain possesses high homology to $\alpha 1$-chain and is proposed to be incorporated as a surrogate of the $\alpha 1$ chain in zebrafish type I collagen [23]. In this study, zebrafish fibroblasts were cultured at temperatures between 18 and $33{ }^{\circ} \mathrm{C}$, and the thermal stability and post-translational modifications of secreted collagen, as well as the $\alpha$-chain compositions of type I collagen, were analyzed.

\section{Results}

\subsection{Western Blot Analysis of Proteins Expressed by ZF4 Cells Cultured at Different Temperatures}

In this study, zebrafish embryonic fibroblasts (ZF4) were used. Although ZF4 cells are cultured at approximately $28{ }^{\circ} \mathrm{C}$, the cells could proliferate at $18,23,28$, and $33{ }^{\circ} \mathrm{C}$ (data not shown). ZF4 cells were first cultured to confluence at $28^{\circ} \mathrm{C}$, and then at 18,23 , 28 , and $33{ }^{\circ} \mathrm{C}$ for 3 days. Then, the media were collected, and western blotting using biotinylated denatured collagen-binding peptide (soCMP6-7(Glu)2) [24] was performed to compare the amount of secreted collagen normalized to protein content in the cell layer (Figure 1a). Because the molecular sizes of $\alpha 1(\mathrm{I})$ and $\alpha 1(\mathrm{I})$ with the unprocessed C-terminal propeptide $(\mathrm{pC} \alpha 1(\mathrm{I}))$ are almost equal to those of $\alpha 3(\mathrm{I})$ and $\alpha 3(\mathrm{I})$ with unprocessed C- 
terminal propeptide ( $\mathrm{pC} \alpha 3(\mathrm{I}))$, respectively, their bands could not be resolved by SDSPAGE. The amount of secreted collagen was relatively small at low $\left(18^{\circ} \mathrm{C}\right)$ and high $\left(33^{\circ} \mathrm{C}\right)$ temperatures compared with the medium $\left(23\right.$ and $\left.28^{\circ} \mathrm{C}\right)$ temperatures. In particular, the band density of $\mathrm{pC} \alpha 1(\mathrm{I})+\mathrm{pC} \alpha 3(\mathrm{I}), \alpha 1(\mathrm{I})+\alpha 3(\mathrm{I})$, and $\alpha 2(\mathrm{I})$-chains in the lanes of the 23 and $28{ }^{\circ} \mathrm{C}$ samples were higher than those of the 18 and $33^{\circ} \mathrm{C}$ samples. In addition, the electrophoretic mobilities of $\mathrm{pC} \alpha 1(\mathrm{I})+\mathrm{pC} \alpha 3(\mathrm{I}), \mathrm{pC} \alpha 2(\mathrm{I})$, and $\alpha 1(\mathrm{I})+\alpha 3(\mathrm{I})$-chains were slightly lower in the $33^{\circ} \mathrm{C}$ sample than in the other samples, suggesting that the molecular size of these polypeptide chains increased at $33^{\circ} \mathrm{C}$.

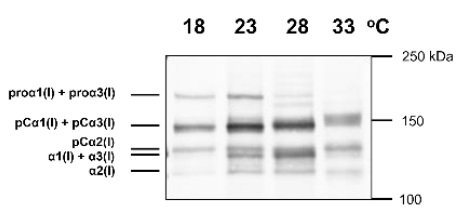

b

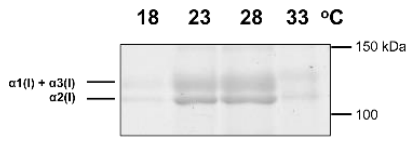

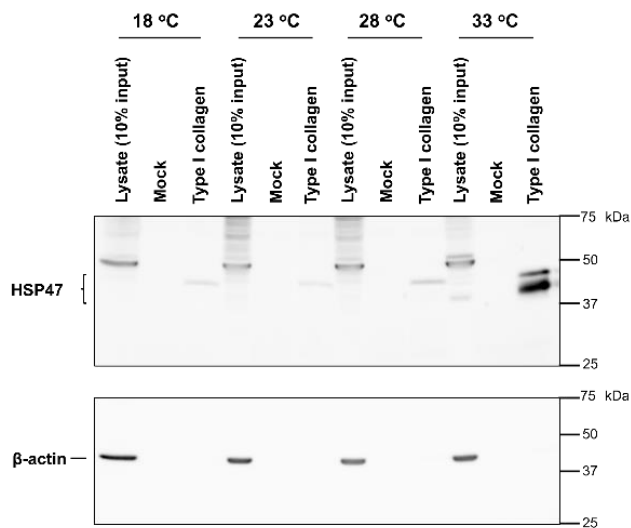

Figure 1. Analysis of extracellular collagen and intracellular HSP47 proteins in ZF4 cells cultured at different temperatures. (a) The loaded amount of SDS samples prepared from culture media was normalized to the protein amount of the cell layer. SDS samples are loaded onto SDS-PAGE gel $(5 \%)$ under reducing conditions. After transfer to a nitrocellulose membrane, collagen polypeptides were detected by using biotinylated soCMP6-7(Glu)2. (b) The culture media of ZF4 cells was treated with pepsin at $4{ }^{\circ} \mathrm{C}$, and the triple-helical region of collagen was purified through salt precipitation. SDS-PAGE (5\%) was performed under nonreducing conditions. Proteins were visualized with CBB. (c) HSP47 was pulled down from the lysate of ZF4 cells using type I collagen-coupled beads or mock-coupled beads. The SDS samples were subjected to SDS-PAGE (10\%) under nonreducing conditions, and western blotting was performed using an antibody against HSP47 (top). The same membranes were reprobed with the anti- $\beta$-actin antibody (bottom).

We next investigated whether the increase in the molecular size of collagen was attributed to the increase in the molecular size of the triple-helical region. We analyzed collagen samples prepared by pepsin treatment at $4{ }^{\circ} \mathrm{C}$, followed by salt precipitation of culture supernatant. The collagen samples were separated by SDS-PAGE, and the protein bands were visualized by Coomassie Brilliant Blue R-250 (CBB) staining. The electrophoretic mobilities of $\alpha 1(\mathrm{I})+\alpha 3(\mathrm{I})$ and $\alpha 2(\mathrm{I})$-chains secreted at $33{ }^{\circ} \mathrm{C}$ decreased compared with those secreted at other culture temperatures (Figure 1b). These results suggest that excessive post-translational modifications occur in the triple-helical region of collagen at $33{ }^{\circ} \mathrm{C}$. Considering the difference in band mobilities, we hypothesized an increase in lysyl glycosylation at $33{ }^{\circ} \mathrm{C}$. Furthermore, a comparison of $\alpha 1(\mathrm{I})+\alpha 3(\mathrm{I})$ and $\alpha 2(\mathrm{I})$ band intensities in each sample revealed that the ratio of $\alpha 1(\mathrm{I})+\alpha 3(\mathrm{I})$ to $\alpha 2(\mathrm{I})$ was relatively higher in the sample at $33{ }^{\circ} \mathrm{C}$ than at other temperatures.

Because the procollagen-specific chaperone HSP47 is heat-inducible, we examined whether HSP47 content changes according to the culture temperature. ZF4 cells cultured for 3 days at $18,23,28$, and $33^{\circ} \mathrm{C}$ were lysed in lysis buffer containing $1 \%$ Nonidet $\mathrm{P}-40$ (NP-40). HSP47 was concentrated from the lysates using type I collagen-immobilized beads. The amount of HSP47 in the samples was compared by western blotting (Figure 1c). $\beta$ Actin was used as a loading control. Although the anti-HSP47 (anti-SERPINH1) polyclonal antibodies could not detect zebrafish HSP47 sensitively in cell lysates, the HSP47 bands were detectable after the protein was concentrated using collagen-immobilized beads. Bands at approximately $50 \mathrm{kDa}$ may be nonspecific because they were observed only in 
cell lysate samples and did not exhibit collagen binding. The amount of HSP47 was almost constant from 18 to $28{ }^{\circ} \mathrm{C}$, whereas it significantly increased at $33{ }^{\circ} \mathrm{C}$. Previous microarray analysis of zebrafish gene expression showed that HSP47 gene expression was almost the same below $28{ }^{\circ} \mathrm{C}$ but increased more than 10 -fold at a higher temperature $\left(34^{\circ} \mathrm{C}\right)[25]$, which is consistent with the results of this study. Two distinct bands of HSP47 were detected in the sample for the $33{ }^{\circ} \mathrm{C}$ culture (Figure 1c). In addition to HSP47 (serpinh $1 b$ ), zebrafish have HSP47-like (serpinh1a), which may have been detected as different bands. However, both HSP47 and HSP47-like have two glycosylation sites; therefore, the two bands may represent differences in glycosylation [26].

\subsection{Quantification of Total Post-Translational Modifications of Collagen}

The molecular size of the triple-helical region of collagen secreted by ZF4 cells at $33{ }^{\circ} \mathrm{C}$ increased (Figure $1 \mathrm{~b}$ ), suggesting an increase in the number of post-translational modifications. We performed amino-acid analysis of acid-hydrolyzed samples to compare the degree of post-translational modification occurring at different culture temperatures. ZF4 cells were cultured for 3 days at $18,23,28$, or $33^{\circ} \mathrm{C}$, and the triple-helical region of collagen was purified from the culture media through pepsin digestion and salt precipitation. The collagen samples were separated using SDS-PAGE, followed by transfer to a polyvinylidene fluoride (PVDF) membrane. Bands of $\alpha 1(\mathrm{I})+\alpha 3(\mathrm{I})$ and $\alpha 2(\mathrm{I})$ were excised, and stable isotope-labeled human collagen (SI-collagen) was added to the excised bands as an internal standard for LC-MS analysis of Pro, 3-Hyp, 4-Hyp, Lys, and total Hyl (Hyl and glycosylated Hyl) generated after acid hydrolysis [27]. The quantitative results, expressed as residues per 1000 residues, are shown in Table S1. From the results obtained, 4-Hyp ratio (4-Hyp /(Pro + 4-Hyp + 3-Hyp)), 3-Hyp ratio (3-Hyp/(Pro + 4-Hyp + 3-Hyp)), and total Hyl ratio (total Hyl/(Lys + total Hyl)) were estimated (Figure 2).

The 4-Hyp and total Hyl ratios increased in a temperature-dependent manner in both $\alpha 1(\mathrm{I})+\alpha 3(\mathrm{I})$ and $\alpha 2(\mathrm{I})$. The ratio of Pro residues at position $Y$ to all Pro residues in the triple-helical region of zebrafish collagen is $50 \%$ for $\alpha 1(\mathrm{I})+\alpha 3(\mathrm{I})$ and $43 \%$ for $\alpha 2(\mathrm{I})$ (Table S2a). The 4-Hyp ratio, even in the collagen secreted from ZF4 at $18{ }^{\circ} \mathrm{C}$, was $48 \%$ in $\alpha 1(\mathrm{I})+\alpha 3(\mathrm{I})$ and $40 \%$ in $\alpha 2(\mathrm{I})$. Because almost all Pro residues at position $\mathrm{Y}$ were converted to 4-Hyp, few Pro residues to remained be 4-hydroxylated, resulting in the relatively small increase in the 4-Hyp ratio with increasing temperature (Figure 2, left). Lys residues at position $\mathrm{Y}$, which can be modified to Hyl, account for $66 \%$ and $63 \%$ of Lys in $\alpha 1$ (I) and $\alpha 3(\mathrm{I})$, respectively, and $71 \%$ in $\alpha 2(\mathrm{I})$ (Table S2b). In collagen secreted from ZF4 cells at $18{ }^{\circ} \mathrm{C}$, only $26 \%$ of Lys in both $\alpha 1(\mathrm{I})+\alpha 3(\mathrm{I})$ and $\alpha 2(\mathrm{I})$ was converted to Hyl, indicating that many sites remained unmodified. As the environmental temperature increased, the Hyl ratio increased remarkably, reaching $49 \%$ in $\alpha 1(\mathrm{I})+\alpha 3(\mathrm{I})$ and $50 \%$ in $\alpha 2(\mathrm{I})$ at $33{ }^{\circ} \mathrm{C}$ (Figure 2 , middle). Acidlabile glycosylated Hyl could not be analyzed here. However, given the increasing degrees of the analyzed modifications at $33^{\circ} \mathrm{C}$ and slight mass shift upon hydroxylation of Pro and Lys (+16 Da) residues, the decrease in electrophoretic mobility of collagen at the higher temperature was strongly suggestive (Figure 1b) of the increase in Hyl glycosylation. By contrast, the number of 3-Hyp residues markedly increased only in collagen secreted from ZF4 cells at $33^{\circ} \mathrm{C}$ (Figure 2, right). These results indicate that the increase in environmental temperature increases the number of post-translational modifications, but the temperature sensitivity was different according to modification types.

\subsection{Quantification of Site-Specific 3-Hyp Modification}

Focusing on prolyl 3-hydroxylation, a relatively rare post-translational modification in collagen, we further analyzed the effect of culture temperature on prolyl 3-hydroxylation at specific Pro residues of each $\alpha$-chain in type I collagen. Although information on the positions of 3-hydroxylation in fish collagen is absent, the known sites (Pro ${ }^{707}$, Pro ${ }^{716}$, Pro ${ }^{719}$, and $\mathrm{Pro}^{986}$ at position $\mathrm{X}$ of Gly-X-4-Hyp) in mammalian collagen for the modification are mostly conserved in zebrafish (Figure S1) [28]. 
ZF4 cells were cultured for 3 days at different temperatures. Collagen samples were prepared and subjected to trypsin digestion to estimate the relative abundance of 3-Hyp at the specific sites using LC-MS (Figure 3).
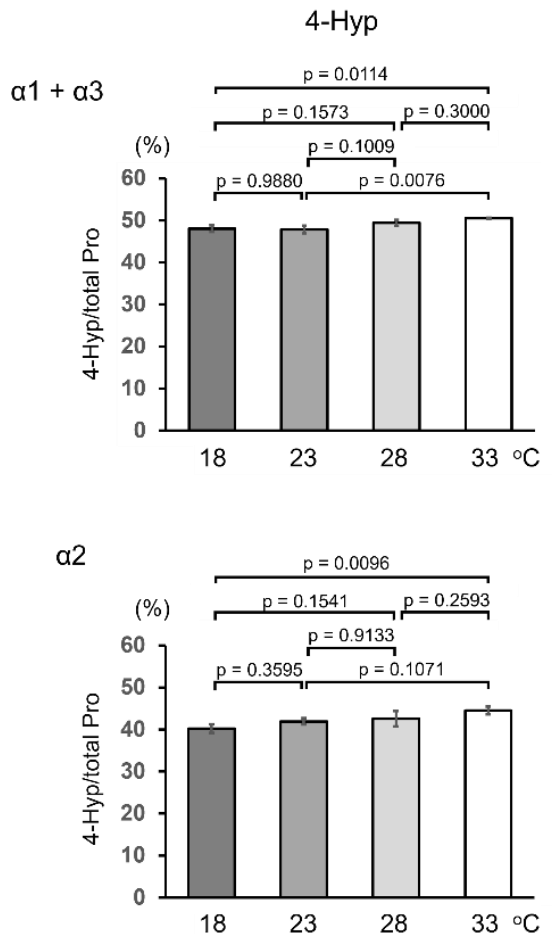
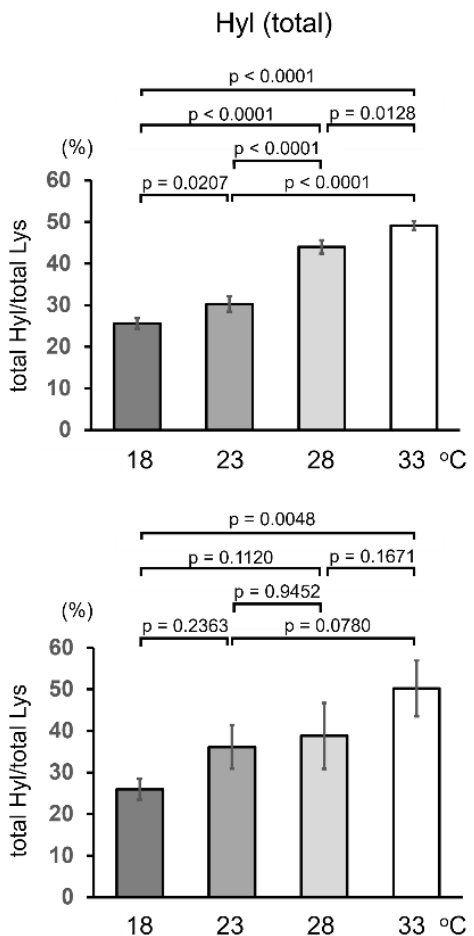
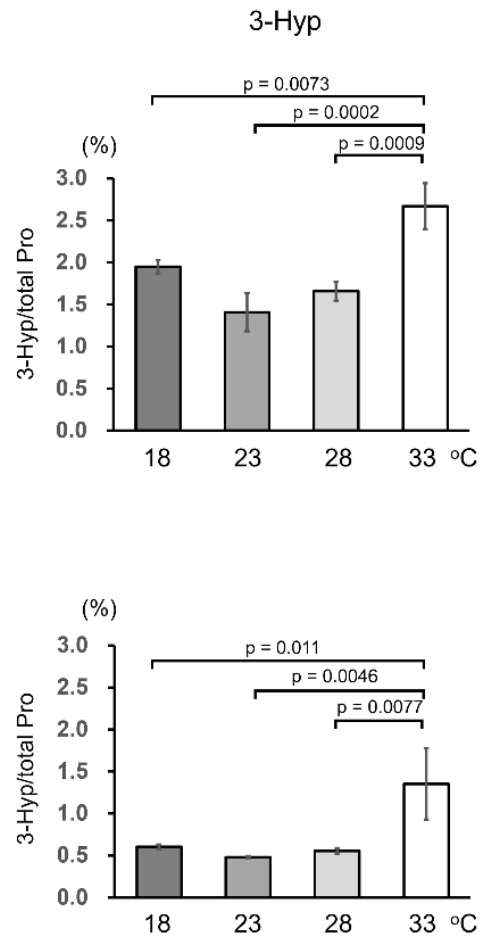

Figure 2. Quantification of total post-translational modifications in type I collagen secreted from ZF4 cells. Culture media of ZF4 cells grown at $4{ }^{\circ} \mathrm{C}$ was pepsin-treated, and collagen was purified through salt precipitation. Purified collagen was subjected to SDS-PAGE and transferred to a PVDF membrane. Then, $\alpha 1(\mathrm{I})+\alpha 3(\mathrm{I})$ and $\alpha 2$ (I) bands were excised and subjected to acid hydrolysis with SI-collagen. Pro, Lys, 3-Hyp, 4-Hyp, and total Hyl (Hyl + glycosylated Hyl) were quantified using LC-MS. Values for 4-Hyp (4-Hyp/(Pro + 4-Hyp + 3-Hyp)), total Hyl (total Hyl/(Lys + total Hyl)), and 3-Hyp (3-Hyp/(Pro + 4-Hyp + 3-Hyp)) ratios were calculated. Values are means $\pm \mathrm{SD}(n=3)$. Differences of means were assessed by one-way ANOVA followed by a Tukey's post-hoc test.

Reportedly, in types I and II collagen of teleosts, including zebrafish, Pro is not hydroxylated at the 3-hydroxylation sites known in mammals [29]. In this study, LC-MS analysis revealed a +16 Da mass shift of Pro residues at the known 3-hydroxylation sites in $\alpha 1(\mathrm{I}), \alpha 2(\mathrm{I})$, and $\alpha 3(\mathrm{I})$ of zebrafish. These findings strongly suggest the presence of 3-Hyp at these sites, which is consistent with results from a study on rat collagen [28]. Furthermore, although 3-hydroxylation of $\alpha 2$ (I) Pro ${ }^{986}$ has not been reported in mammals, 3-hydroxylation of this site was detected in ZF4 cells (Figure S1). In collagen secreted from ZF4 cells at 18,23 , and $28{ }^{\circ} \mathrm{C}$, no marked difference in the number of 3-Hyp residues at any analyzed peptide fragment was observed; however, 3-Hyp number markedly increased only in collagen secreted from ZF4 cells at $33{ }^{\circ} \mathrm{C}$ (Figure 3 ). These results are consistent with changes in the number of 3-Hyp residues at different temperatures (Figure 2).

\section{4. $\alpha$-Chain Ratios of Type I Collagen Secreted from ZF4 Cells}

Because the number of each $\alpha$-chain in secreted type I collagen changed according to the culture temperature (Figure 1a,b), we quantified the relative number of $\alpha$ chains. Collagen samples purified from the culture media of ZF4 cells were digested with trypsin and the generated marker peptides of each $\alpha$-chain were analyzed using LC-MS (Figure 4 and Tables S3 and S4). We used ${ }^{15} \mathrm{~N}$-enriched synthetic peptides (Figure S2 and Table S5) as internal standards for MS analysis. The ratio of each $\alpha$-chain to total $\alpha$-chains was almost constant below $28^{\circ} \mathrm{C}$. However, at $33{ }^{\circ} \mathrm{C}$, the $\alpha 1$ ratio increased (from $40-42 \%$ 
to $55 \%$ ) and decreased both $\alpha 2$ and $\alpha 3$ ratios (from $28-31 \%$ to $22-23 \%$ ). This result indicates that the proportion of $\alpha$-chains in type I collagen secreted from ZF4 cells depends on culture temperature, and dramatic changes occurred around $33^{\circ} \mathrm{C}$.

$\alpha 1(I)$

VGP ${ }^{707}$ OGPSGNSGP ${ }^{716}$ OGP ${ }^{719}$ OGPAGK

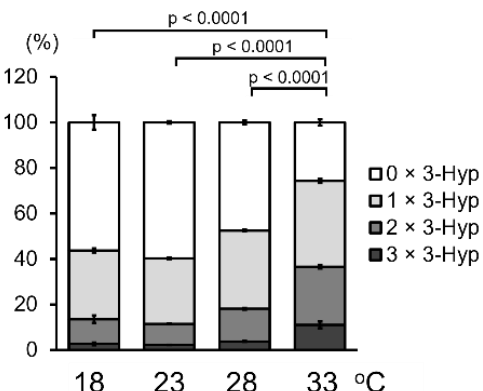

$\alpha 2(I)$

VGP707OGPAGIVGPAGLTGPAGK

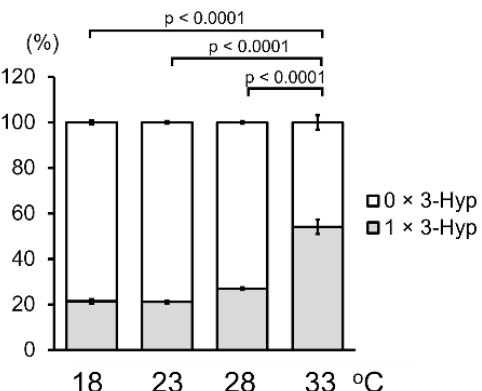

a3(I)

[705-725]

\section{DGMSGLOGPIGP986OGPR}

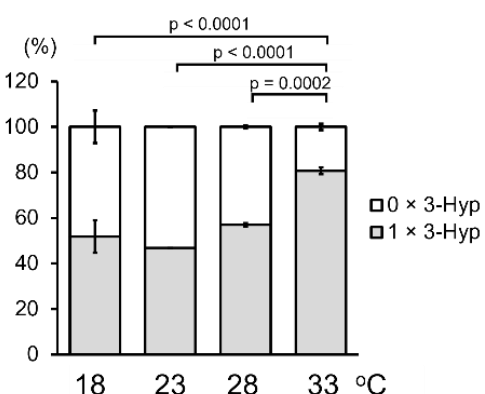

DGSNGMOGAIGP986OGHR

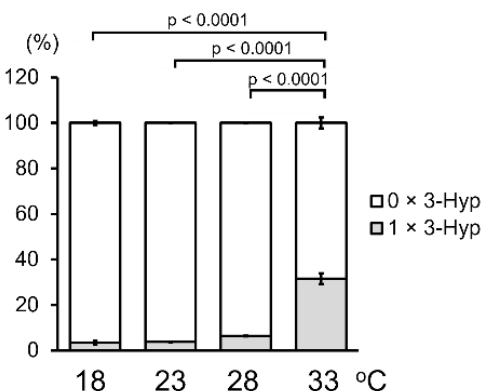

VGP ${ }^{707}$ OGPSGASGP ${ }^{716}$ OGPTGPAGK

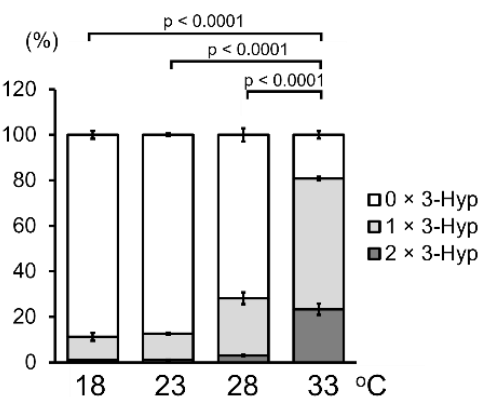

[975-990]

Figure 3. Quantification of site-specific 3-Hyp in type I collagen secreted from ZF4 cells. After pepsin treatment of culture media of ZF4 cells at $4{ }^{\circ} \mathrm{C}$, collagen was purified through salt precipitation. Purified collagen was heat denatured and trypsin digested. LC-MS analysis was performed to quantify 3-Hyp at specific sites (indicated as boldface letters in the sequences). O indicates 4-Hyp. Values are means $\pm \mathrm{SD}(n=3)$. Differences of means in the $0 \times 3$-Hyp (unmodified Pro) were assessed by one-way ANOVA followed by Tukey's post hoc test.

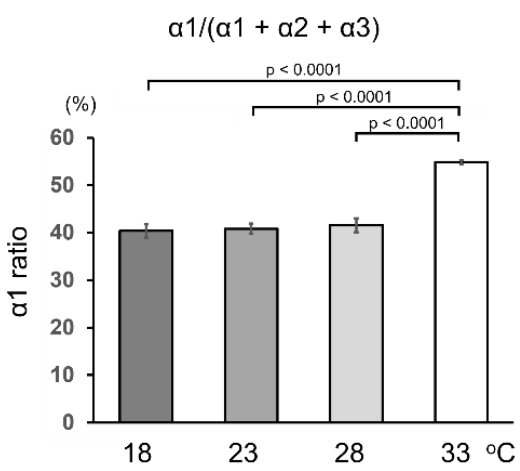

$\alpha 2 /(\alpha 1+\alpha 2+\alpha 3)$

$\alpha 3 /(\alpha 1+\alpha 2+\alpha 3)$
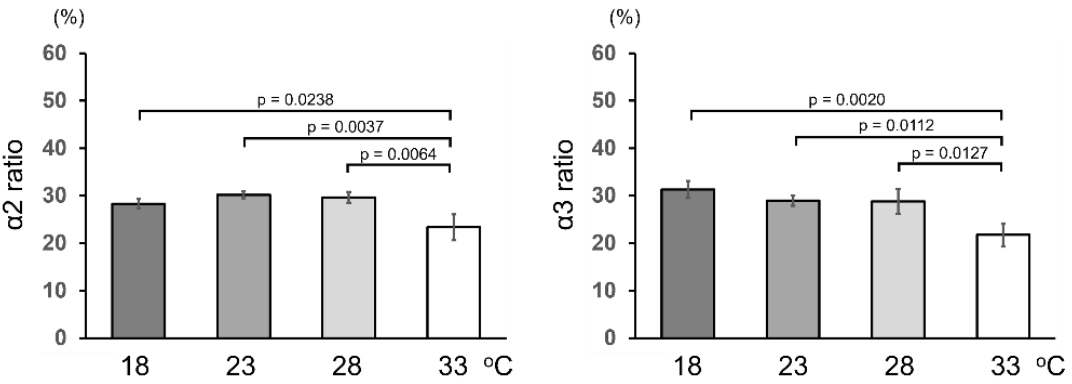

Figure 4. Quantification of type I collagen $\alpha$-chains secreted from ZF4 cells. Pepsinized collagen was purified from the culture media through salt precipitation. The samples were digested with trypsin after adding stable isotope-labeled synthetic peptides and heat denatured. The amount of each $\alpha$-chain of type I collagen was determined through LC-MS analysis of marker peptides. Values are means $\pm \mathrm{SD}(n=3)$. Differences of means were assessed by one-way ANOVA followed by Tukey's post hoc test.

The positions of cysteine residues in the C-propeptide domains of $\alpha$-chains were reported to determine the combinations of $\alpha$-chains involved in triple helix-formation [30]. 
Trimers with the chain-arrangements of $(\alpha 1)_{3},\left[(\alpha 1)_{2} \alpha 3\right],\left[(\alpha 1)_{2} \alpha 2\right]$, and $[\alpha 1 \alpha 2 \alpha 3]$ are possible for zebrafish type I collagen. Using data shown in Figure 4 and Table S4, we simulated the ratios of these trimers secreted from ZF4 cells at each temperature. Details of the calculations are described in Section 4.8. Because quantification data were insufficient to calculate the actual ratios of the trimers, the calculation was performed assuming variables $\mathrm{x}, \mathrm{y}, \mathrm{z}$, and $\mathrm{w}(\%)$, as the ratios of $\left[(\alpha 1)_{2} \alpha 3\right]$ at $18,23,28$, and $33{ }^{\circ} \mathrm{C}$, respectively. As shown in Table 1 , the ratio of $[\alpha 1 \alpha 2 \alpha 3]$ to total trimer was at least $75.3-78.5 \%$ at $18-28{ }^{\circ} \mathrm{C}$, but at most $65.2 \%$ at $33{ }^{\circ} \mathrm{C}$, indicating that the $[\alpha 1 \alpha 2 \alpha 3]$ ratio decreased at $33^{\circ} \mathrm{C}$ compared with other temperatures. A wide range of values due to the influence of variables made a precise comparison of other trimer ratios among different temperatures challenging. Instead, of comparing individual ratios of trimers, the sum of the ratios of two trimers was compared. The sum of ratios of $(\alpha 1)_{3}$ and $\left[(\alpha 1)_{2} \alpha 3\right]$ and that of ratios of $(\alpha 1)_{3}$ and $\left[(\alpha 1)_{2} \alpha 2\right]$ were estimated to be highest at $33^{\circ} \mathrm{C}$ (Table 1 ). The sum ratio values of $(\alpha 1)_{3}$ and $\left[(\alpha 1)_{2} \alpha 3\right]$ were calculated to be $15.1 \%$ at $18{ }^{\circ} \mathrm{C}, 9.4 \%$ at $23{ }^{\circ} \mathrm{C}, 11.1 \%$ at $28{ }^{\circ} \mathrm{C}$, and $29.9 \%$ at $33{ }^{\circ} \mathrm{C}$. Those of $(\alpha 1)_{3}$ and $\left[(\alpha 1)_{2} \alpha 2\right]$ were estimated to be $6.1 \%$ at $18{ }^{\circ} \mathrm{C}, 13.1 \%$ at $23{ }^{\circ} \mathrm{C}, 13.6 \%$ at $28{ }^{\circ} \mathrm{C}$, and $34.8 \%$ at $33{ }^{\circ} \mathrm{C}$.

Table 1. Trimer ratios in type I collagen secreted from ZF4 cells.

\begin{tabular}{|c|c|c|c|c|c|c|}
\hline \multirow{2}{*}{$\begin{array}{c}\text { Culture } \\
\text { Temperature }\end{array}$} & $(\alpha 1)_{3}$ & {$\left[(\alpha 1)_{2} \alpha 3\right]$} & {$\left[(\alpha 1)_{2} \alpha 2\right]$} & {$[\alpha 1 \alpha 2 \alpha 3]$} & $(\alpha 1)_{3}+\left[(\alpha 1)_{2} \alpha 3\right]$ & $(\alpha 1)_{3}+\left[(\alpha 1)_{2} \alpha 2\right]$ \\
\hline & $\begin{array}{c}\text { Average (SD) } \\
(\%)\end{array}$ & $\begin{array}{c}\text { Average (SD) } \\
(\%)\end{array}$ & $\begin{array}{c}\text { Average (SD) } \\
(\%)\end{array}$ & $\begin{array}{c}\text { Average (SD) } \\
(\%)\end{array}$ & $\begin{array}{c}\text { Average (SD) } \\
(\%)\end{array}$ & $\begin{array}{c}\text { Average (SD) } \\
(\%)\end{array}$ \\
\hline $18^{\circ} \mathrm{C}$ & $\begin{array}{c}15.1(3.1)-\mathrm{x} \\
\max : 6.1(x=9.0) \\
\min : 0(x=15.1)\end{array}$ & $\begin{array}{c}\mathrm{x} \\
\max : 15.1(x=15.1) \\
\min : 9.0(x=9.0)\end{array}$ & $\begin{array}{c}-9.0(7.6)+\mathrm{x} \\
\max : 6.1(x=15.1) \\
\min : 0(x=9.0)\end{array}$ & $\begin{array}{c}93.9(5.4)-\mathrm{x} \\
\max : 84.6(x=9.0) \\
\min : 78.5(x=15.1)\end{array}$ & $15.1(3.1)$ & $6.1(5.4)$ \\
\hline $23^{\circ} \mathrm{C}$ & $\begin{array}{c}9.4(2.2)-\mathrm{y} \\
\max : 9.4(y=0) \\
\min : 0(y=9.4)\end{array}$ & $\begin{array}{c}\mathrm{y} \\
\max : 9.4(y=9.4) \\
\min : 0(y=0)\end{array}$ & $\begin{array}{c}3.7(4.5)+y \\
\max : 13.1(y=9.4) \\
\min : 3.7(y=0)\end{array}$ & $\begin{array}{c}86.9(3.3)-\mathrm{y} \\
\max : 86.9(y=0) \\
\min : 77.8(y=9.1)\end{array}$ & $9.4(2.2)$ & $13.1(3.3)$ \\
\hline $28^{\circ} \mathrm{C}$ & $\begin{array}{l}11.1(3.5)-z \\
\max : 11.1(z=0) \\
\min : 0(z=11.1)\end{array}$ & $\begin{array}{c}\mathrm{z} \\
\max : 11.1(z=11.1) \\
\min : 0(z=0)\end{array}$ & $\begin{array}{c}2.4(11.2)+z \\
\max : 13.5(z=11.1) \\
\min : 2.4(z=0)\end{array}$ & $\begin{array}{c}86.4(7.8)-\mathrm{z} \\
\max : 86.4(z=0) \\
\min : 75.3(z=11.1)\end{array}$ & $11.1(3.5)$ & $13.6(7.8)$ \\
\hline $33^{\circ} \mathrm{C}$ & $\begin{array}{c}29.9(8.2)-\mathrm{w} \\
\max : 29.9(w=0) \\
\min : 0(w=29.9)\end{array}$ & $\begin{array}{c}\mathrm{w} \\
\max : 29.9(w=29.9) \\
\min : 0(w=0)\end{array}$ & $\begin{array}{c}4.9(15.4)+w \\
\max : 34.8(w=29.9) \\
\min : 4.9(w=0)\end{array}$ & $\begin{array}{c}65.2(7.3)-\mathrm{w} \\
\max : 65.2(w=0) \\
\min : 35.3(w=29.9)\end{array}$ & $29.9(8.2)$ & $34.8(7.3)$ \\
\hline
\end{tabular}

$9.0 \leq \mathrm{x} \leq 15.1,0 \leq \mathrm{y} \leq 9.4,0 \leq \mathrm{z} \leq 11.1,0 \leq \mathrm{w} \leq 29.9 . n=3$.

\subsection{Thermal Stability of Collagen Triple-Helical Structure Secreted from ZF4 Cells}

We compared the thermal stability of the triple-helical structure of type I collagen secreted from ZF4 cells cultured at different temperatures. The triple helix collagen samples were similarly prepared, and polypeptide chain conformation was analyzed by circular dichroism (CD) spectrometry. Thermal melting curves were obtained by plotting fraction folded, calculated by measuring ellipticity values at $221 \mathrm{~nm}$, with increasing temperature (Figure 5). The melting temperatures of the collagen triple helix were estimated to be $34.2,34.8,34.4$, and $36.4{ }^{\circ} \mathrm{C}$ for the $18,23,28$, and $33^{\circ} \mathrm{C}$ samples, respectively. This result indicates that the thermal stability of type I collagen is almost constant below $28^{\circ} \mathrm{C}$ and is markedly enhanced at a higher temperature $\left(33^{\circ} \mathrm{C}\right)$. This increase in thermal stability may be caused by an increase in post-translational modification and/or a change in the $\alpha$-chain composition of type I collagen, which was observed in the experiments described above.

To investigate the effect of the $\alpha$-chain arrangements on the thermal stability of the triple helix, we performed computational simulation and compared the relative thermal stability of the triple helices of zebrafish type I collagen molecules with different chain arrangements. We used SCEPTTr, an empirical algorithm that predicts the melting temperature of the triple-helical structure of collagen-model peptides [31]. In the collagen triple helix, three polypeptide chains intertwine with one another, with one-residue staggers along the helical axis. Therefore, in a heterotrimer consisting of two A-chains and one B-chain, the B-chain occupies either the leading (BAA), middle (ABA), or trailing (AAB) position, resulting in three isomers. There are six isomers in a heterotrimer consisting of one A-chain, one B-chain, and one C-chain, accordingly. Considering that only $(\alpha 1)_{3},\left[(\alpha 1)_{2} \alpha 2\right]$, $\left[(\alpha 1)_{2} \alpha 3\right]$, and $[\alpha 1 \alpha 2 \alpha 3]$ are suggested to form zebrafish type I collagen, we predicted 13 
isoforms, including chain-staggering isomers. Of these, we excluded three chain-staggering isoforms having $\alpha 2$-chain as the middle strand, because $\alpha 1 \alpha 2 \alpha 1$ is unlikely to form in mammals [32,33], and zebrafish $\alpha 3$-chain can be placed as a surrogate for the $\alpha 1$-chain, judging by their homology [23]. Taken together, we hypothesized that ten different type I collagen molecules can form in zebrafish (Table 2).

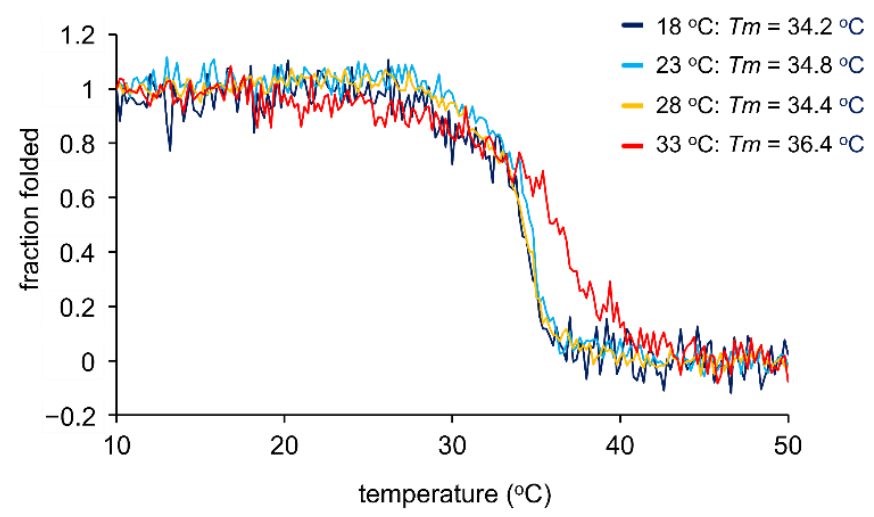

Figure 5. Thermal melting curves for collagen triple helix obtained by CD spectrometry. ZF4 cells were cultured for 3 days at the temperatures indicated. After the culture media were treated with pepsin at $4{ }^{\circ} \mathrm{C}$, collagen was isolated by salt precipitation. CD signal was measured at $221 \mathrm{~nm}$ with increasing temperature $\left(0.25^{\circ} \mathrm{C} / \mathrm{min}\right)$. The melting temperature $(\mathrm{Tm})$ was set to the temperature at which the fraction folded was 0.5 .

Table 2. Simulation of the relative thermal stability of zebrafish type I collagen with different chain compositions.

\begin{tabular}{ccc}
\hline$\alpha$-Chain Composition & Chain Stagger & Virtual Relative Thermal Stability $\left({ }^{\circ} \mathbf{C}\right)$ \\
\hline$(\alpha 1)_{3}$ & $\alpha 1 \alpha 1 \alpha 1$ & 40.7 \\
\hline \multirow{2}{*}[(\alpha1)_{2}\alpha3]{} & $\alpha 1 \alpha 1 \alpha 3$ & 39.9 \\
& $\alpha 3 \alpha 1 \alpha 1$ & 39.7 \\
& $\alpha 1 \alpha 3 \alpha 1$ & 39.3 \\
\hline \multirow{2}{*}[(\alpha1)_{2}\alpha2]{} & $\alpha 2 \alpha 1 \alpha 1$ & 39.0 \\
& $\alpha 1 \alpha 1 \alpha 2$ & 38.8 \\
\hline \multirow{2}{*}[\alpha1\alpha2\alpha3]{} & $\alpha 2 \alpha 3 \alpha 1$ & 38.0 \\
& $\alpha 2 \alpha 1 \alpha 3$ & 37.9 \\
& $\alpha 1 \alpha 3 \alpha 2$ & 37.7 \\
& $\alpha 3 \alpha 1 \alpha 2$ & 37.5 \\
\hline
\end{tabular}

Each isoform's virtual relative thermal stability was calculated as the average of the predicted melting temperatures for 334 collagen-derived peptide fragments of 45 aminoacid residues flanked by (Pro-Hyp-Gly) 5 at both $\mathrm{N}$ - and C-terminus. All Pro residues at position $\mathrm{Y}$ were substituted with 4-Hyp residues in this calculation (Table 2 and Figure S3). The thermal stability of the possible isoforms of zebrafish type I collagen was predicted to be higher in the order of $(\alpha 1)_{3},\left[(\alpha 1)_{2} \alpha 3\right],\left[(\alpha 1)_{2} \alpha 2\right]$, and [ $\left.\alpha 1 \alpha 2 \alpha 3\right]$. The effect of chain stagger was too little to affect the order of the thermal stability of the isoforms. The simulation results suggest that isoforms with more $\alpha 1$-chains have relatively higher thermal stability. Data shown in Table 1 reveal that the sums of ratios of relatively stable isoforms $\left((\alpha 1)_{3}\right.$ $+\left[(\alpha 1)_{2} \alpha 3\right]$ and $\left.(\alpha 1)_{3}+\left[(\alpha 1)_{2} \alpha 2\right]\right)$ increased at $33{ }^{\circ} \mathrm{C}$, whereas the relatively unstable $[\alpha 1 \alpha 2 \alpha 3]$ ratio decreased. Thus, changes in $\alpha$-chain composition may contribute to the higher thermal stability of secreted collagen at $33^{\circ} \mathrm{C}$.

\section{Discussion}

Because the enzymes involved in procollagen post-translational modifications recognize only the single-stranded portions as substrate [12], the modifications should last 
until triple helix-formation is completed in the ER. The amount of 4-Hyp in collagen was reported to increase in a temperature-dependent manner when full-length unmodifiedpolypeptide chains were treated with prolyl 4-hydroxylase [34-36]. Furthermore, 4-Hyp stabilizes the triple-helical structure significantly [2]; 3-hydroxylation of Pro may also stabilize it [6]. Modifications of Lys side chains affect the thermal stability of the triple helix $[7,8]$. The secretion of procollagen involves TANGO1; Tango1-null mice show abnormal bone formation due to delayed collagen secretion [37]. TANGO1 is involved in the formation of large COPII vesicles [38,39] and tunnels from the ER to the Golgi [40]. TANGO1 probably contributes to the selective secretion of procollagen forming the triple helix by interacting with HSP47, which binds to the triple-helical structure of procollagen [41]. By contrast, misfolded procollagen is recognized by calnexin in the ER and degraded through autophagy [13]. These findings suggest that procollagen is stabilized in the ER lumen by either extensive post-translational modifications or assistance by HSP47 until the formation of the triple helix is completed. Only procollagen molecules with the triple-helical structure are secreted to the extracellular space via the Golgi. In this study, we hypothesized a mechanism that provides sufficient thermal stability based on environmental temperature and tested this hypothesis.

Quantification of post-translationally modified amino-acid residues in zebrafish type I collagen secreted at different temperatures showed a temperature-dependent increase in 4-Hyp levels. However, the rate of the change was low (Figure 2), probably because the Pro residues at position $\mathrm{Y}$ receive 4-hydroxylation nearly quantitatively even at $18{ }^{\circ} \mathrm{C}$. The amount of total $\mathrm{Hyl}$ also increased with increasing culture temperature. An increase in the amount of 3-Hyp and glycosylated Hyl was observed only at $33^{\circ} \mathrm{C}$, indicating a delay in triple helix-formation in the ER. The temperature-dependent changes in the ratios of such minor modifications appeared more significantly than major modifications, such as prolyl 4-hydroxylation, probably because more unmodified substrate sequences remained in $\alpha$-chains. Quantification of $\alpha$-chains of type I collagen secreted at different temperatures revealed that the ratio of $\alpha 1$-chain was higher, and the ratios of $\alpha 2$ and $\alpha 3$-chains were lower only at $33^{\circ} \mathrm{C}$ (Figure 4). Simulation analysis using the algorithm suggested that the change in $\alpha$-chain composition at $33^{\circ} \mathrm{C}$ increases the thermal stability of collagen (Tables 1 and 2). Although the simulation cannot predict the actual melting temperature of the collagen triple helix, it allowed a relative comparison of thermal stability among the collagen isoforms. The melting temperatures of the collagen triple helix were almost constant between culture temperatures 18 and $28{ }^{\circ} \mathrm{C}$, whereas only collagen secreted at $33^{\circ} \mathrm{C}$ showed a higher melting temperature (Figure 5). This is probably due to factors including an increase in prolyl 3-hydroxylation (Figure 2) and changes in the $\alpha$-chain composition of type I collagen (Figure 4). An increase of Hyl glycosylation (Figure 1) may also affect thermal stability. The significant difference in the character of zebrafish type I collagen secreted at $33^{\circ} \mathrm{C}$ would be a consequence of the quality control mechanism ensuring triple-helical conformation. However, we cannot exclude the possibility of secretion of unfolded collagen that could have been degraded with pepsin treatment at $4{ }^{\circ} \mathrm{C}$ during sample preparation.

Post-translational modifications of procollagen $\alpha$-chains start immediately after translocating to the ER lumen [12]. Co-translational modifications and interaction with HSP47 provide sufficient stability to the triple helix to be folded below $28^{\circ} \mathrm{C}$ (Figure 6). Increased post-translational modifications, altered $\alpha$-chain composition, and the resulting increase in thermal stability of collagen secreted by ZF4 cells at $33^{\circ} \mathrm{C}$ are similar to collagen abnormalities observed in $h s p 47$-null mouse fibroblasts [18]. They may be due to the destabilization of the procollagen triple helix in the ER. Although ZF4 cells induce the expression of HSP47 at $33^{\circ} \mathrm{C}$, it may have been insufficient to cope with the destabilization of the procollagen triple-helical structure. Therefore, procollagen has acquired higher thermal stability by further post-translational modifications and changes in $\alpha$-chain composition (Figure 6). Consistent with the results of this study, it has been reported that human skin fibroblasts also secrete over-modified collagen when cultured at a high temperature of $40.5^{\circ} \mathrm{C}$ [42]. 
$18,23,28^{\circ} \mathrm{C}$
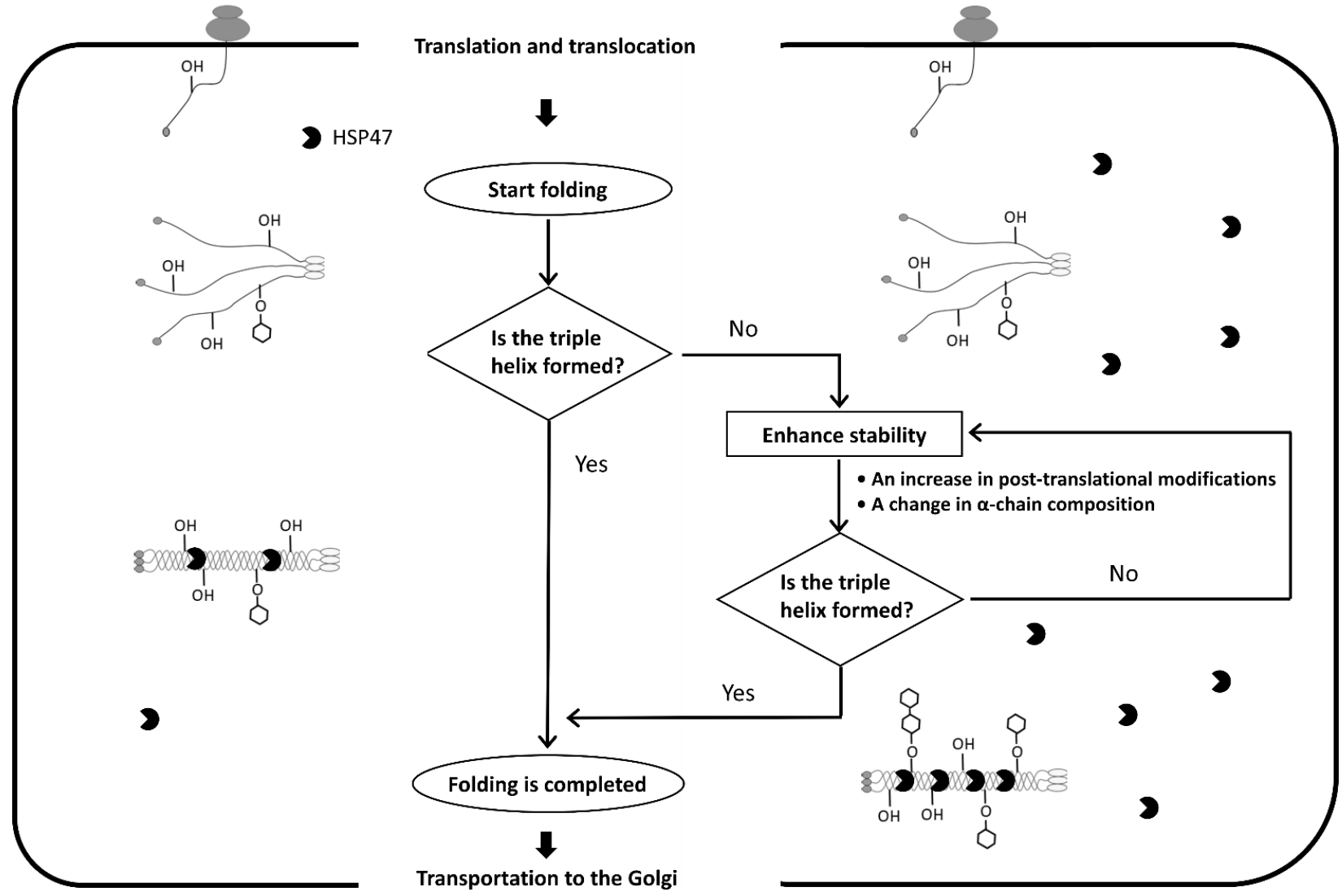

Figure 6. A possible mechanism for tuning triple-helix stability according to the environmental temperature. When ZF4 cells were cultured below $28^{\circ} \mathrm{C}$, the thermal stability of the procollagen triple helix is almost constant because of the contribution of co-translational modifications. At a higher temperature of $33^{\circ} \mathrm{C}$, the additional mechanism to ensure thermal stability of procollagen triple helix is executed.

In vivo, temperature differences may lead to collagen production with different properties. Collagen in muscle tissue was reported to show higher thermal stability than collagen in skin tissue [43-45]. In addition, the amount of 4-Hyp and Hyl in collagen could also vary depending on the tissue [46]. These results indicate that differences in temperature in tissues may cause these differences. Core body temperature is higher than peripheral body temperature in homeotherms, and this temperature difference can also affect the properties of collagen. The melting temperature of collagen in human bone is higher than that of the skin, and an increase of post-translational modifications in bone collagen has been observed [47].

Mammalian type I collagen molecule is a $\left[(\alpha 1)_{2} \alpha 2\right]$ heterotrimer. However, the presence of $(\alpha 1)_{3}$ homotrimer in fetal [48] and cancer [49-53] tissues has been elucidated. Cancer cells can reportedly migrate along the collagenase-resistant homotrimers as a scaffold [49]. Consistent with results from the simulation of thermal stability comparison among different zebrafish type I collagen molecules (Table 2 ), the melting temperature of mammalian $(\alpha 1)_{3}$ homotrimers is higher than that of $\left[(\alpha 1)_{2} \alpha 2\right]$ heterotrimers $[54,55]$. The temperature of breast cancer tissue was reported to be higher than that of surrounding normal tissues, with a difference of up to $3.5^{\circ} \mathrm{C}[56,57]$. Our findings suggest that the secretion of the relatively higher thermally stable isoforms, with more $\alpha 1$-chains $\left((\alpha 1)_{3},\left[(\alpha 1)_{2} \alpha 3\right]\right.$, $\left.\left[(\alpha 1)_{2} \alpha 2\right]\right)$, increased at a higher temperature of $33^{\circ} \mathrm{C}$ (Tables 1 and 2$)$. High temperatures may contribute to the secretion of $(\alpha 1)_{3}$ homotrimers that have higher thermal stability than $\left[(\alpha 1)_{2} \alpha 2\right]$ heterotrimers in mammalian tissues. We showed that the thermal stability 
of the collagen triple helix could be tuned depending on the environmental temperature by altering the amount of post-translational modifications and $\alpha$-chain compositions. It is tempting to speculate that collagen with different properties produced through this mechanism has different roles in vivo.

\section{Materials and Methods}

\subsection{Cell Culture}

ZF4 cells were purchased from ATCC (CRL-2050). The cells were cultured in a 1:1 mixture of Dulbecco's Modified Eagle's Medium and Ham's F-12 (DMEM/Ham's F12, Wako Pure Chemical Industries, Osaka, Japan) supplemented with 10\% fetal bovine serum (FBS), $100 \mathrm{U} / \mathrm{mL}$ penicillin, and $100 \mu \mathrm{g} / \mathrm{mL}$ streptomycin (Sigma-Aldrich, St. Louis, MO, USA) at $28{ }^{\circ} \mathrm{C}$ in an atmosphere of $5 \% \mathrm{CO}_{2}$.

For all experiments, the cells were maintained at $18,23,28$, or $33{ }^{\circ} \mathrm{C}$ for one day for acclimation after they became confluent. The medium was replaced with DMEM/Ham's F12 containing $200 \mu \mathrm{M}$ L-ascorbic acid phosphate magnesium salt $n$-hydrate (Wako Pure Chemical Industries, Osaka, Japan), 2\% FBS, $100 \mathrm{U} / \mathrm{mL}$ penicillin, and $100 \mu \mathrm{g} / \mathrm{mL}$ streptomycin. The cells were maintained at $18,23,28$, or $33{ }^{\circ} \mathrm{C}$ in a $5 \% \mathrm{CO}_{2}$ atmosphere for 3 days and used for the experiments.

\subsection{SDS-PAGE Analysis of Pepsin-Treated Collagen Samples}

Culture media from $\mathrm{ZF} 4$ cells cultured at different temperatures for 3 days was centrifuged $(2290 \times g)$ at $4{ }^{\circ} \mathrm{C}$ for $15 \mathrm{~min}$, and the supernatant was treated with $100 \mu \mathrm{g} / \mathrm{mL}$ pepsin (Sigma-Aldrich, St. Louis, MO, USA) in $0.1 \mathrm{~N} \mathrm{HCl}$ at $4{ }^{\circ} \mathrm{C}$ for $16 \mathrm{~h}$. Collagen samples were isolated by salting out $(1 \mathrm{M} \mathrm{NaCl} / 0.1 \mathrm{~N} \mathrm{HCl})$ at $4{ }^{\circ} \mathrm{C}$ for $3 \mathrm{~h}$. The precipitates obtained through centrifugation $\left(4^{\circ} \mathrm{C}, 20,900 \times g, 15 \mathrm{~min}\right)$ were dissolved in SDS-PAGE sample buffer (50 mM Tris-HCl [pH 6.7], 10\% glycerol, 2\% SDS, and 0.002\% bromophenol blue) and heated at $95{ }^{\circ} \mathrm{C}$ for $5 \mathrm{~min}$. SDS-PAGE was performed on a $5 \%$ gel under nonreducing conditions, and the protein bands were visualized with $\mathrm{CBB}$.

\subsection{Western Blotting Analysis of Culture Media Samples and Pull-Down Samples}

After the culture media was collected from ZF4 cells cultured at different temperatures for 3 days, the cells were washed with phosphate-buffered saline (PBS) and treated with lysis buffer (1\% NP-40, $150 \mathrm{mM} \mathrm{NaCl}, 5.0 \mathrm{mM}$ EDTA, $50 \mathrm{mM}$ Tris- $\mathrm{HCl}$ (pH 8.0), $2.0 \mathrm{mM} \mathrm{N-}$ ethylmaleimide, $1.0 \mathrm{mM}$ phenylmethylsulfonyl fluoride, $1 \mu \mathrm{g} / \mathrm{mL}$ leupeptin, and $1 \mu \mathrm{g} / \mathrm{mL}$ pepstatin A) on ice for $15 \mathrm{~min}$. After centrifugation $(20,600 \times \mathrm{g})$ at $4{ }^{\circ} \mathrm{C}$ for $15 \mathrm{~min}$, soluble protein in the supernatant was quantified using the Bradford method. For concentrating HSP47, $500 \mu \mathrm{L}$ of the lysate (protein concentration: $5 \mathrm{mg} / \mathrm{mL}$ ) was mixed with $100 \mu \mathrm{L}-\mathrm{bed}$ of type I collagen (AteloCell I-AC30, Koken, Tokyo, Japan), coupled or mock-coupled with CNBr-activated Sepharose 4B (GE Healthcare, Piscataway, NJ, USA) beads. Samples were rotated at $4{ }^{\circ} \mathrm{C}$ for $2 \mathrm{~h}$ and washed with $0.4 \mathrm{M} \mathrm{NaCl} / \mathrm{PBS}$. Then, the protein bound to the beads was eluted by adding $100 \mu \mathrm{L}$ of $2 \times$ SDS sample buffer, followed by heating at $95{ }^{\circ} \mathrm{C}$ for $5 \mathrm{~min}$. To prepare the lysate and media samples, $5 \times$ SDS sample buffer was added to the lysate and culture medium and heated at $95^{\circ} \mathrm{C}$ for $5 \mathrm{~min}$.

For western blot analysis of media samples, the amount of medium per unit protein extracted from the cell layer was calculated and loaded onto the gel. SDS-PAGE was performed using a 5\% gel for the media samples in the presence of $91 \mathrm{mM} \mathrm{1,4-dithiothreitol}$ (DTT) or $10 \%$ gel for the pull-down samples. Proteins were transferred to nitrocellulose membranes. The membranes were blocked with 5\% skim milk/Tris-buffered saline (TBS; $50 \mathrm{mM}$ Tris- $\mathrm{HCl}$ pH 7.4, $150 \mathrm{mM} \mathrm{NaCl}$ ) for $1 \mathrm{~h}$ and washed with TBS. The membranes were treated with the primary antibody or $3 \mu \mathrm{g} / \mathrm{mL}$ of biotin-labeled soCMP6-7(Glu) 2 in $2 \%$ skim milk/TBS to detect HSP47 or collagen [24], respectively. Then, the membranes were washed with TBS, treated with the secondary antibody or streptavidin-alkaline phosphatase (Promega, Madison, WI, USA, 1:1000 dilution) in 2\% skim milk/TBS, respectively, and washed with TBS containing $0.1 \%$ Tween-20. HSP47 bands were detected using the CCD 
imager LAS-3000 (Fujifilm, Tokyo, Japan) with Pierce ${ }^{\mathrm{TM}}$ ECL western blotting substrate kit (Thermo Fisher Scientific, Waltham, MA, USA). Collagen bands were visualized using the alkaline phosphatase conjugate substrate kit (Bio-Rad Laboratories, Hercules, CA, USA).

The primary antibodies used included the anti-SERPINH1 rabbit polyclonal antibody (MBS835022, MyBioSource, San Diego, CA, USA, 1:250 dilution) and anti- $\beta$-actin monoclonal antibody (A5316, Sigma-Aldrich, St. Louis, MO, USA, 1:2000 dilution); the secondary antibodies were goat anti-rabbit IgG-HRP conjugate (7074S, Cell Signaling Technology, Danvers, MA, USA, 1:2000 dilution), and goat anti-mouse IgG-HRP conjugate (W402B, Promega, Madison, WI, USA, 1:5000 dilution), respectively.

\subsection{Synthesis of Stable Isotope-Labeled Peptides}

Stable isotope-labeled marker peptides corresponding to tryptic marker peptides for quantifying zebrafish $\alpha 1(\mathrm{I}), \alpha 2(\mathrm{I})$, and $\alpha 3$ (I)-chains were prepared by 9-fluorenylmethoxycarbonyl (Fmoc) solid-phase peptide synthesis on Wang resin using Fmoc $-{ }^{15} \mathrm{~N}-\mathrm{Gly}-\mathrm{OH}$ (Sigma-Aldrich, St. Louis, MO, USA). The peptide resin was treated with trifluoroacetic acid $/ \mathrm{H}_{2} \mathrm{O} / \mathrm{m}$-cresol/thioani sole $/ 1,2$-ethanedithiol $(82.5 / 5 / 5 / 5 / 2.5, v / v)$ for 2 or $4 \mathrm{~h}$ at about $25^{\circ} \mathrm{C}$. The deprotected peptides were purified through RP-HPLC on a Cosmosil 5C18-AR-II column $(6.0 \mathrm{~mm} \times 250 \mathrm{~mm}$, Nacalai Tesque, Kyoto, Japan) with $\mathrm{CH}_{3} \mathrm{CN}$ in water, both containing $0.05 \%(v / v)$ TFA. The desired peptides were analyzed using RP-HPLC on a Cosmosil 5C18-AR-II column $(4.6 \mathrm{~mm} \times 250 \mathrm{~mm}$, Nacalai Tesque, Kyoto, Japan) with a linear gradient of $\mathrm{CH}_{3} \mathrm{CN}$ in $\mathrm{H}_{2} \mathrm{O}$, both containing $0.05 \%$ $(v / v)$ TFA. Mass spectrometric analysis was performed with Autoflex III MALDI-TOF MS (Bruker Daltonics, Bremen, Germany). To determine the absolute amount of these peptides, amino-acid analysis was performed using an L-8900 amino-acid analyzer (Hitachi, Tokyo, Japan) after acid hydrolysis with $6 \mathrm{~N} \mathrm{HCl} / 1 \%$ phenol at $110^{\circ} \mathrm{C}$ for $20 \mathrm{~h}$ in the gas phase under $\mathrm{N}_{2}$.

\subsection{Quantification of Type I Collagen $\alpha$-Chains by LC-MS}

The culture media of ZF4 cells cultured for 3 days was centrifuged $\left(2290 \times g, 4{ }^{\circ} \mathrm{C}\right.$, $15 \mathrm{~min})$, and the supernatant was collected. The supernatant was treated with pepsin at $4{ }^{\circ} \mathrm{C}$ in $0.1 \mathrm{~N} \mathrm{HCl}$ after adding SI-collagen, and collagen was isolated through salt precipitation. The collagen samples were heat-denatured at $60^{\circ} \mathrm{C}$ for $30 \mathrm{~min}$ and digested with sequencing grade modified trypsin (Promega, Madison, WI, USA) at $37^{\circ} \mathrm{C}$ for $16 \mathrm{~h}$ in $100 \mathrm{mM}$ Tris- $\mathrm{HCl} / 1 \mathrm{mM} \mathrm{CaCl}_{2}$ (pH 7.6), after adding the stable isotope-labeled peptides as internal standards. We selected two tryptic marker peptides for each $\alpha$-chain $(\alpha 1$ (I) 421-434, $\alpha 1$ (I) 688-704, $\alpha 2$ (I) 351-360, $\alpha 2$ (I) 502-519, $\alpha 3$ (I) 295-309, and $\alpha 3$ (I) 421-434). The marker peptides were analyzed by LC-MS in multiple reaction monitoring (MRM) mode on a 3200 QTRAP hybrid triple quadrupole (QqQ)/linear ion trap mass spectrometer (AB Sciex, Foster City, CA, USA) coupled to an Agilent 1200 Series HPLC system (Agilent Technologies, Palo Alto, CA, USA) using the BIOshell A160 Peptide C18 HPLC column ( $5 \mu \mathrm{m}$ particle size, $\mathrm{L} \times$ I.D. $150 \mathrm{~mm} \times 2.1 \mathrm{~mm}$; Supelco, Bellefonte, PA, USA) to quantify each $\alpha$-chain based on the peak area ratio relative to the corresponding internal standard peptides as described [18]. Stable isotopically heavy human type I collagen marker peptides from SI-collagen [27] were also analyzed to correct sampling errors. After quantifying the $1 \% \mathrm{NP}-40$ soluble protein in the cells as shown in Section 4.3, the amount of secreted type I collagen $\alpha$-chains per amount of protein in the cells was calculated (Table S3).

\subsection{Quantification of Total Post-Translational Modifications in Collagen by LC-MS}

Total levels of post-translational modifications in collagen were estimated by LC-MS as described [18]. Briefly, collagen samples purified from the culture media of ZF4 cells were subjected to SDS-PAGE ( $5 \%$ gel) under nonreducing conditions, and the gel was electroblotted onto a PVDF membrane. The membrane was stained with CBB, and the bands of $\alpha 1(\mathrm{I})+\alpha 3$ (I) and $\alpha 2(\mathrm{I})$-chains were cut out from the membrane. SI-collagen was added as an internal standard, and the excised bands were subjected to acid hydrolysis $\left(6 \mathrm{~N} \mathrm{HCl} / 1 \%\right.$ phenol, $110^{\circ} \mathrm{C}$ for $20 \mathrm{~h}$ in the gas phase under $\mathrm{N}_{2}$ ). Pro, 3-Hyp, 4-Hyp, Lys, and total $\mathrm{Hyl}(\mathrm{Hyl}+$ glycosylated $\mathrm{Hyl}$ ) were quantified by LC-QqQ-MS in MRM mode 
following chromatographic separation using the ZIC-HILIC column ( $3.5 \mu \mathrm{m}$ particle size, $\mathrm{L} \times$ I.D. $150 \mathrm{~mm} \times 2.1 \mathrm{~mm}$; Merck Millipore, Billerica, MA, USA) [18].

\subsection{Site-Specific Characterization of Prolyl 3-Hydroxylation in Zebrafish Type I Collagen by LC-MS}

The purified collagen samples were digested with trypsin as described above to evaluate the relative abundance of prolyl 3-hydroxylation at specific sites in zebrafish type I collagen by LC-MS. The tryptic digests were analyzed by LC-MS on the maXis II quadrupole time-of-flight mass spectrometer (Bruker Daltonics, Bremen, Germany) coupled to the Shimadzu Prominence UFLC-XR system (Shimadzu, Kyoto, Japan) using the Ascentis Express C18 HPLC column ( $5 \mu \mathrm{m}$ particle size, $\mathrm{L} \times$ I.D. $150 \mathrm{~mm} \times 2.1 \mathrm{~mm}$; Supelco, Bellefonte, PA, USA). Site occupancy of prolyl 3-hydroxylation at respective modification sites was semi-quantitatively estimated by the relative peak area ratio of monoisotopic extracted ion chromatograms for each 3-Hyp variant of tryptic peptides containing the modification sites described previously [58].

\subsection{Calculation of the Amount Ratios of Possible Trimers in Type I Collagen}

The amount ratios of $\alpha 1, \alpha 2$, and $\alpha 3$-chains to total $\alpha$-chains $(\alpha 1+\alpha 2+\alpha 3)$ of type I collagen are described as $r_{\alpha 1}, r_{\alpha 2}$, and $r_{\alpha 3}$, respectively. The amount ratios of $(\alpha 1)_{3},\left[(\alpha 1)_{2} \alpha 3\right]$, $\left[(\alpha 1)_{2} \alpha 2\right]$, and $[\alpha 1 \alpha 2 \alpha 3]$ to total trimers $\left((\alpha 1)_{3}+\left[(\alpha 1)_{2} \alpha 3\right]+\left[(\alpha 1)_{2} \alpha 2\right]+[\alpha 1 \alpha 2 \alpha 3]\right)$ of type I collagen are described as $R_{(\alpha 1) 3}, R_{[(\alpha 1) 2 \alpha 3]}, R_{[(\alpha 1) 2 \alpha 2]}$, and $R_{[\alpha 1 \alpha 2 \alpha 3]}$, respectively. $r_{\alpha 1}, r_{\alpha 2}$, and $r_{\alpha 3}$ are formulated from $R_{(\alpha 1) 3}, R_{[(\alpha 1) 2 \alpha 3]}, R_{[(\alpha 1) 2 \alpha 2]}$, and $R_{[\alpha 1 \alpha 2 \alpha 3]}$.

$$
\begin{gathered}
r_{\alpha 1}=\left(3 R_{(\alpha 1) 3}+2 R_{[(\alpha 1) 2 \alpha 3]}+2 R_{[(\alpha 1) 2 \alpha 2]}+R_{[\alpha 1 \alpha 2 \alpha 3]}\right) / 3 \\
r_{\alpha 2}=\left(R_{[(\alpha 1) 2 \alpha 2]}+R_{[\alpha 1 \alpha 2 \alpha 3]}\right) / 3 \\
r_{\alpha 3}=\left(R_{[(\alpha 1) 2 \alpha 3]}+R_{[\alpha 1 \alpha 2 \alpha 3]}\right) / 3
\end{gathered}
$$

To calculate the ratios of trimers using the observed data, $\mathrm{r}_{\alpha 1}, \mathrm{r}_{\alpha 2}$, and $\mathrm{r}_{\alpha 3}$, shown in Figure 4 and Table S4, Equations (1)-(3) were organized as Equations (4)-(6).

$$
\begin{gathered}
R_{(\alpha 1) 3}=r_{\alpha 1}-2 r_{\alpha 2}+r_{\alpha 3}-R_{[(\alpha 1) 2 \alpha 3]} \\
R_{[(\alpha 1) 2 \alpha 2]}=3\left(r_{\alpha 2}-r_{\alpha 3}\right)+R_{[(\alpha 1) 2 \alpha 3]} \\
R_{[\alpha 1 \alpha 2 \alpha 3]}=3 r_{\alpha 3}-R_{[(\alpha 1) 2 \alpha 3]}
\end{gathered}
$$

The amount ratios of individual trimers were calculated from Equations (4)-(6), and the results are shown in Table $1 . R_{[(\alpha 1) 2 \alpha 3]}$ at $18,23,28$, and $33^{\circ} \mathrm{C}$ was given as variables $x$, $\mathrm{y}, \mathrm{z}$, and $\mathrm{w}$, respectively. As all the trimer ratios must be positive values, the variable $\mathrm{x}$ is greater than or equal to 9.0 so that $R_{[(\alpha 1) 2 \alpha 2]}$ at $18^{\circ} \mathrm{C}$ is 0 or more. The other variables $y, z$, and $w$ are all greater than or equal to 0 so that $R_{[(\alpha 1) 2 \alpha 3]}$ at 23,28 , and $33^{\circ} \mathrm{C}$ are 0 or more. In addition, $\mathrm{x} \leq 15.1, \mathrm{y} \leq 9.4, \mathrm{z} \leq 11.1$, and $\mathrm{w} \leq 29.9$ are satisfied so that $\mathrm{R}_{(\alpha 1) 3}$ is 0 or more.

\subsection{Measurement of the Melting Temperature of Collagen}

The collagen samples purified from the culture media of ZF4 cells by pepsin digestion and salt precipitation were dissolved in $10 \mathrm{mM}$ acetic acid, and CD signals at $221 \mathrm{~nm}$ were measured with the J-820 CD spectropolarimeter (Jasco, Tokyo, Japan) equipped with a Peltier thermal controller while heating $\left(0.25{ }^{\circ} \mathrm{C} / \mathrm{min}\right)$. CD signals at $221 \mathrm{~nm}$ were normalized to the fraction folded. Tm values are temperatures at which fraction folded is 0.5 .

\subsection{Prediction of Relative Thermal Stability of Possible Isoforms of Zebrafish Type I Collagen}

The amino-acid sequences of the $\alpha 1, \alpha 2$, and $\alpha 3$-chains of zebrafish type I collagen were obtained from Uniprot database (https: / / www.uniprot.org/, accessed on 5 January 2022; D. rerio $\alpha 1(\mathrm{I}):$ NP_954684.1, $\alpha 2(\mathrm{I}):$ NP_892013.2, $\alpha 3(\mathrm{I}):$ NP_958886.1). All the Pro at 
position $\mathrm{Y}$ in the triple-helical region (Gly-X-Y) consisting of 1014 amino-acid residues were converted to 4-Hyp. The converted sequences of the triple-helical regions were divided into 334 sequences of 15 amino-acid residue fragments by shifting three residues from each $\alpha$-chain. The relative stability of 334 sites was predicted as the sequences attached five repeats of Gly-Pro-4-Hyp triplets at both $\mathrm{N}$ - and C-terminus for the 10 possible isoforms of zebrafish type I collagen by SCEPTTr (Figure S3) [31]. Chain stagger was adopted with one-residue offset. The virtual relative thermal stability of each isoform was calculated as the average of predicted relative stability for 334 peptides of 45 amino-acid residues.

\subsection{Statistical Analysis}

The results are presented as means $\pm \mathrm{SD}$. Differences of means were assessed by one-way ANOVA and Tukey's multiple comparison test using a GraphPad Prism software version 7.04 (GraphPad Software, La Jolla, CA, USA).

\section{Conclusions}

In general, the thermal stability of a protein conformation is determined a priori by its primary structure. In this study, by using poikilotherm cells, we elucidated that the thermal stability of the collagen triple helix was tuned according to the environmental temperature. The secreted collagen acquires higher thermal stability by a change in $\alpha$-chain composition and an increase in post-translational modifications through an ad hoc mechanism at a high temperature above the threshold.

Supplementary Materials: The following supporting information can be downloaded at: https: //www.mdpi.com/article/10.3390/ijms23042040/s1.

Author Contributions: Conceptualization, K.K.F. and T.K.; formal analysis, Y.K.T.; investigation, K.K.F. and Y.T.; writing — original draft preparation, K.K.F.; writing — review and editing, Y.T., R.M., S.H. and T.K.; supervision, S.H. and T.K. All authors have read and agreed to the published version of the manuscript.

Funding: This paper is a part of the outcome of research performed under a Waseda University Grant for Special Research Projects (Project number: 2020C-292).

Institutional Review Board Statement: Not applicable.

Informed Consent Statement: Not applicable.

Data Availability Statement: The data presented in this study are available in the article or Supplementary Materials.

Conflicts of Interest: The authors declare no conflict of interest.

\section{References}

1. Ricard-Blum, S. The Collagen Family. Cold Spring Harb. Perspect. Biol. 2011, 3, a004978. [CrossRef] [PubMed]

2. Berg, R.A.; Prockop, D.J. The Thermal Transition of a Non-Hydroxylated Form of Collagen. Evidence for a Role for Hydroxyproline in Stabilizing the Triple-Helix of Collagen. Biochem. Biophys. Res. Commun. 1973, 52, 115-120. [CrossRef]

3. Burjanadze, T.V. Hydroxyproline Content and Location in Relation to Collagen Thermal Stability. Biopolymers 1979, 18, 931-938. [CrossRef] [PubMed]

4. Burjanadze, T.V. New Analysis of the Phylogenetic Change of Collagen Thermostability. Biopolymers 2000, 53, 523-528. [CrossRef]

5. Taga, Y.; Tanaka, K.; Hattori, S.; Mizuno, K. In-Depth Correlation Analysis Demonstrates That 4-Hydroxyproline at the Yaa Position of Gly-Xaa-Yaa Repeats Dominantly Stabilizes Collagen Triple Helix. Matrix Biol. Plus 2021, 10, 100067. [CrossRef]

6. Mizuno, K.; Peyton, D.H.; Hayashi, T.; Engel, J.; Bächinger, H.P. Effect of the -Gly-3(S)-Hydroxyprolyl-4(R)-HydroxyprolylTripeptide Unit on the Stability of Collagen Model Peptides. FEBS J. 2008, 275, 5830-5840. [CrossRef]

7. Nokelainen, M.; Helaakoski, T.; Myllyharju, J.; Notbohm, H.; Pihlajaniemi, T.; Fietzek, P.P.; Kivirikko, K.I. Expression and Characterization of Recombinant Human Type II Collagens with Low and High Contents of Hydroxylysine and Its Glycosylated Forms. Matrix Biol. 1998, 16, 329-338. [CrossRef]

8. Takuwa, A.; Yoshida, T.; Maruno, T.; Kawahara, K.; Mochizuki, M.; Nishiuchi, Y.; Kobayashi, Y.; Ohkubo, T. Ordered SelfAssembly of the Collagenous Domain of Adiponectin with Noncovalent Interactions via Glycosylated Lysine Residues. FEBS Lett. 2016, 590, 195-201. [CrossRef] 
9. Duan, R.; Konno, K.; Zhang, J.; Wang, S.; Yuan, C. Different Thermostability of Collagens from Scale of Carp (Cyprinus carpio) in Winter and Summer. J. Food Biochem. 2010, 34, 1275-1287. [CrossRef]

10. Engel, J.; Prockop, D.J. The Zipper-like Folding of Collagen Triple Helices and the Effects of Mutations That Disrupt the Zipper. Annu. Rev. Biophys. Biophys. Chem. 1991, 20, 137-152. [CrossRef]

11. Koide, T.; Nagata, K. Collagen Biosynthesis. In Collagen: Primer in Structure, Processing and Assembly; Brinckmann, J., Notbohm, H., Müller, P.K., Eds.; Topics in Current Chemistry; Springer: Berlin \Heidelberg, Germany, 2005; pp. 85-114; ISBN 978-3-540-31472-1.

12. Myllyharju, J. Intracellular Post-Translational Modifications of Collagens. In Topics in Current Chemistry; Springer: New York, NY, USA, 2005; Volume 247, pp. 115-147.

13. Forrester, A.; De Leonibus, C.; Grumati, P.; Fasana, E.; Piemontese, M.; Staiano, L.; Fregno, I.; Raimondi, A.; Marazza, A.; Bruno, G.; et al. A Selective ER-Phagy Exerts Procollagen Quality Control via a Calnexin-FAM134B Complex. EMBO J. 2019, 38 , e99847. [CrossRef] [PubMed]

14. Ishida, Y.; Kubota, H.; Yamamoto, A.; Kitamura, A.; Bächinger, H.P.; Nagata, K. Type I Collagen in Hsp47-null Cells Is Aggregated in Endoplasmic Reticulum and Deficient in N-Propeptide Processing and Fibrillogenesis. Mol. Biol. Cell 2006, 17, $2346-2355$. [CrossRef] [PubMed]

15. Koide, T.; Aso, A.; Yorihuzi, T.; Nagata, K. Conformational Requirements of Collagenous Peptides for Recognition by the Chaperone Protein HSP47. J. Biol. Chem. 2000, 275, 27957-27963. [CrossRef] [PubMed]

16. Tasab, M.; Batten, M.R.; Bulleid, N.J. Hsp47: A Molecular Chaperone That Interacts with and Stabilizes Correctly-Folded Procollagen. EMBO J. 2000, 19, 2204-2211. [CrossRef] [PubMed]

17. Nagai, N.; Hosokawa, M.; Itohara, S.; Adachi, E.; Matsushita, T.; Hosokawa, N.; Nagata, K. Embryonic Lethality of Molecular Chaperone Hsp47 Knockout Mice Is Associated with Defects in Collagen Biosynthesis. J. Cell Biol. 2000, 150, 1499-1506. [CrossRef]

18. Fujii, K.K.; Taga, Y.; Sakai, T.; Ito, S.; Hattori, S.; Nagata, K.; Koide, T. Lowering the Culture Temperature Corrects Collagen Abnormalities Caused by HSP47 Gene Knockout. Sci. Rep. 2019, 9, 1-11. [CrossRef]

19. Drögemüller, C.; Becker, D.; Brunner, A.; Haase, B.; Kircher, P.; Seeliger, F.; Fehr, M.; Baumann, U.; Lindblad-Toh, K.; Leeb, T. A Missense Mutation in the SERPINH1 Gene in Dachshunds with Osteogenesis Imperfecta. PLOS Genet. 2009, 5, e1000579. [CrossRef]

20. Christiansen, H.E.; Schwarze, U.; Pyott, S.M.; AlSwaid, A.; Al Balwi, M.; Alrasheed, S.; Pepin, M.G.; Weis, M.A.; Eyre, D.R.; Byers, P.H. Homozygosity for a Missense Mutation in SERPINH1, Which Encodes the Collagen Chaperone Protein HSP47, Results in Severe Recessive Osteogenesis Imperfecta. Am. J. Hum. Genet. 2010, 86, 389-398. [CrossRef]

21. Cortemeglia, C.; Beitinger, T.L. Temperature Tolerances of Wild-Type and Red Transgenic Zebra Danios. Trans. Am. Fish. Soc. 2005, 134, 1431-1437. [CrossRef]

22. Schaefer, J.; Ryan, A. Developmental Plasticity in the Thermal Tolerance of Zebrafish Danio Rerio. J. Fish Biol. 2006, 69, 722-734. [CrossRef]

23. Morvan-Dubois, G.; Le Guellec, D.; Garrone, R.; Zylberberg, L.; Bonnaud, L. Phylogenetic Analysis of Vertebrate Fibrillar Collagen Locates the Position of Zebrafish $\alpha 3(\mathrm{I})$ and Suggests an Evolutionary Link between Collagen $\alpha$ Chains and Hox Clusters. J. Mol. Evol. 2003, 57, 501-514. [CrossRef] [PubMed]

24. Takita, K.K.; Fujii, K.K.; Ishii, K.; Koide, T. Structural Optimization of Cyclic Peptides That Efficiently Detect Denatured Collagen Org. Biomol. Chem. 2019, 17, 7380-7387. [CrossRef] [PubMed]

25. Long, Y.; Li, L.; Li, Q.; He, X.; Cui, Z. Transcriptomic Characterization of Temperature Stress Responses in Larval Zebrafish. PLoS ONE 2012, 7, e37209. [CrossRef] [PubMed]

26. Liang, X.; Wan, Y.; Shen, Z.; Liu, Y.; Li, D.; Li, L.; Tang, R.; Zhang, X. Molecular Characterization of Hsp47 in Grass Carp (Ctenopharyngodon Idella) and Its Correlation with Type I Collagen in Response to Fish Aerobic Exercise. Fishes 2021, 6, 17. [CrossRef]

27. Taga, Y.; Kusubata, M.; Ogawa-Goto, K.; Hattori, S. Stable Isotope-Labeled Collagen: A Novel and Versatile Tool for Quantitative Collagen Analyses Using Mass Spectrometry. J. Proteome Res. 2014, 13, 3671-3678. [CrossRef]

28. Taga, Y.; Kusubata, M.; Ogawa-Goto, K.; Hattori, S. Developmental Stage-Dependent Regulation of Prolyl 3-Hydroxylation in Tendon Type I Collagen. J. Biol. Chem. 2016, 291, 837-847. [CrossRef]

29. Tonelli, F.; Cotti, S.; Leoni, L.; Besio, R.; Gioia, R.; Marchese, L.; Giorgetti, S.; Villani, S.; Gistelinck, C.; Wagener, R.; et al. Crtap and P3h1 Knock out Zebrafish Support Defective Collagen Chaperoning as the Cause of Their Osteogenesis Imperfecta Phenotype. Matrix Biol. 2020, 90, 40-60. [CrossRef]

30. DiChiara, A.S.; Li, R.C.; Suen, P.H.; Hosseini, A.S.; Taylor, R.J.; Weickhardt, A.F.; Malhotra, D.; McCaslin, D.R.; Shoulders, M.D. A Cysteine-Based Molecular Code Informs Collagen C-Propeptide Assembly. Nat. Commun. 2018, 9, 4206. [CrossRef]

31. Walker, D.R.; Hulgan, S.A.H.; Peterson, C.M.; Li, I.-C.; Gonzalez, K.J.; Hartgerink, J.D. Predicting the Stability of Homotrimeric and Heterotrimeric Collagen Helices. Nat. Chem. 2021, 13, 260-269. [CrossRef]

32. Kawahara, K.; Yoshida, T.; Maruno, T.; Oki, H.; Ohkubo, T.; Koide, T.; Kobayashi, Y. Spatiotemporal Regulation of PEDF Signaling by Type I Collagen Remodeling. Proc. Natl. Acad. Sci. USA 2020, 117, 11450-11458. [CrossRef]

33. Jalan, A.A.; Sammon, D.; Hartgerink, J.D.; Brear, P.; Stott, K.; Hamaia, S.W.; Hunter, E.J.; Walker, D.R.; Leitinger, B.; Farndale, R.W. Chain Alignment of Collagen I Deciphered Using Computationally Designed Heterotrimers. Nat. Chem. Biol. 2020, 16, 423-429. [CrossRef] [PubMed] 
34. Jimenez, S.A.; Harsch, M.; Murphy, L.; Rosenbloom, J. Effects of Temperature on Conformation, Hydroxylation, and Secretion of Chick Tendon Procollagen. J. Biol. Chem. 1974, 249, 4480-4486. [CrossRef]

35. Murphy, L.; Rosenbloom, J. Evidence That Chick Tendon Procollagen Must Be Denatured to Serve as Substrate for Proline Hydroxylase. Biochem. J. 1973, 135, 249-251. [CrossRef] [PubMed]

36. Berg, R.A.; Prockop, D.J. Purification of $\left({ }^{14} \mathrm{C}\right)$ Protocollagen and Its Hydroxylation by Prolyl-Hydroxylase. Biochemistry 1973, 12, 3395-3401. [CrossRef] [PubMed]

37. Wilson, D.G.; Phamluong, K.; Li, L.; Sun, M.; Cao, T.C.; Liu, P.S.; Modrusan, Z.; Sandoval, W.N.; Rangell, L.; Carano, R.A.D.; et al Global Defects in Collagen Secretion in a Mia3/TANGO1 Knockout Mouse. J. Cell Biol. 2011, 193, 935-951. [CrossRef]

38. Saito, K.; Chen, M.; Bard, F.; Chen, S.; Zhou, H.; Woodley, D.; Polischuk, R.; Schekman, R.; Malhotra, V. TANGO1 Facilitates Cargo Loading at Endoplasmic Reticulum Exit Sites. Cell 2009, 136, 891-902. [CrossRef]

39. Yuan, L.; Kenny, S.J.; Hemmati, J.; Xu, K.; Schekman, R. TANGO1 and SEC12 Are Copackaged with Procollagen I to Facilitate the Generation of Large COPII Carriers. Proc. Natl. Acad. Sci. USA 2018, 115, E12255-E12264. [CrossRef]

40. McCaughey, J.; Stevenson, N.L.; Cross, S.; Stephens, D.J. ER-to-Golgi Trafficking of Procollagen in the Absence of Large Carriers. J. Cell Biol. 2019, 218, 929-948. [CrossRef]

41. Ishikawa, Y.; Ito, S.; Nagata, K.; Sakai, L.Y.; Bächinger, H.P. Intracellular Mechanisms of Molecular Recognition and Sorting for Transport of Large Extracellular Matrix Molecules. Proc. Natl. Acad. Sci. USA 2016, 113, E6036-E6044. [CrossRef]

42. Torre-Blanco, A.; Adachi, E.; Hojima, Y.; Wootton, J.A.; Minor, R.R.; Prockop, D.J. Temperature-Induced Post-Translational Over-Modification of Type I Procollagen. Effects of Over-Modification of the Protein on the Rate of Cleavage by Procollagen N-Proteinase and on Self-Assembly of Collagen into Fibrils. J. Biol. Chem. 1992, 267, 2650-2655. [CrossRef]

43. Kimura, S.; Zhu, X.-P.; Matsui, R.; Shijoh, M.; Takamizawa, S. Characterization of Fish Muscle Type I Collagen. J. Food Sci. 1988, 53, 1315-1318. [CrossRef]

44. Saito, M.; Higuchi, T.; Uchida, N. Identification and Primary Structures of Eel Type I Collagen pro $\alpha 1$, pro $\alpha 2$ and pro $\alpha 3$. Fish. Sci. 2014, 80, 1323-1335. [CrossRef]

45. Saito, M.; Takenouchi, Y.; Kunisaki, N.; Kimura, S. Complete Primary Structure of Rainbow Trout Type I Collagen Consisting of $\alpha 1(\mathrm{I}) \alpha 2(\mathrm{I}) \alpha 3(\mathrm{I})$ Heterotrimers. Eur. J. Biochem. 2001, 268, 2817-2827. [CrossRef]

46. Duan, R.; Zhang, J.; Du, X.; Yao, X.; Konno, K. Properties of Collagen from Skin, Scale and Bone of Carp (Cyprinus carpio). Food Chem. 2009, 112, 702-706. [CrossRef]

47. Notbohm, H.; Mosler, S.; Bodo, M.; Yang, C.; Lehmann, H.; Bätge, B.; Müller, P.K. Comparative Study on the Thermostability of Collagen I of Skin and Bone: Influence of Posttranslational Hydroxylation of Prolyl and Lysyl Residues. J. Protein Chem. 1992, 11, 635-643. [CrossRef]

48. Jimenez, S.; Bashey, R. Identification of Collagen $\alpha 1$ (I) Trimer in Embryonic Chick Tendons and Calvaria. Biochem. Biophys. Res. Commun. 1977, 78, 1354-1361. [CrossRef]

49. Makareeva, E.; Han, S.; Vera, J.C.; Sackett, D.L.; Holmbeck, K.; Phillips, C.L.; Visse, R.; Nagase, H.; Leikin, S. Carcinomas Contain a Matrix Metalloproteinase-Resistant Isoform of Type I Collagen Exerting Selective Support to Invasion. Cancer Res. 2010, 70 , 4366-4374. [CrossRef]

50. Moro, L.; Smith, B.D. Identification of Collagen $\alpha 1$ (I) Trimer and Normal Type I Collagen in a Polyoma Virus-Induced Mouse Tumor. Arch. Biochem. Biophys. 1977, 182, 33-41. [CrossRef]

51. Shapiro, F.D.; Eyre, D.R. Collagen Polymorphism in Extracellular Matrix of Human Osteosarcoma. J. Natl. Cancer Inst. 1982, 69, 1009-1016. [CrossRef]

52. Yamagata, S.; Yamagata, T. FBJ Virus-Induced Osteosarcoma Contains Type I, Type I Trimer, Type III as Well as Type V Collagens J. Biochem. 1984, 96, 17-26. [CrossRef]

53. Minafra, I.P.; Luparello, C.; Sciarrino, S.; Tomasino, R.M.; Minafra, S. Quantitative Determination of Collagen Types Present in the Ductal Infiltrating Carcinoma of Human Mammary Gland. Cell Biol. Int. Rep. 1985, 9, 291-296. [CrossRef]

54. Kuznetsova, N.V.; McBride, D.J.; Leikin, S. Changes in Thermal Stability and Microunfolding Pattern of Collagen Helix Resulting from the Loss of $\alpha 2$ (I) Chain in Osteogenesis Imperfecta Murine. J. Mol. Biol. 2003, 331, 191-200. [CrossRef]

55. Miles, C.A.; Sims, T.J.; Camacho, N.P.; Bailey, A.J. The Role of the $\alpha 2$ Chain in the Stabilization of the Collagen Type I Heterotrimer: A Study of the Type I Homotrimer in oim Mouse Tissues. J. Mol. Biol. 2002, 321, 797-805. [CrossRef]

56. Bray, F.; Ferlay, J.; Soerjomataram, I.; Siegel, R.L.; Torre, L.A.; Jemal, A. Global Cancer Statistics 2018: GLOBOCAN Estimates of Incidence and Mortality Worldwide for 36 Cancers in 185 Countries. CA Cancer J. Clin. 2018, 68, 394-424. [CrossRef]

57. Lawson, R.N.; Chughtai, M.S. Breast Cancer and Body Temperature. Can. Med. Assoc. J. 1963, 88, 68-70.

58. Ishikawa, Y.; Taga, Y.; Zientek, K.; Mizuno, N.; Salo, A.M.; Semenova, O.; Tufa, S.F.; Keene, D.R.; Holden, P.; Mizuno, K.; et al. Type I and Type V Procollagen Triple Helix Uses Different Subsets of the Molecular Ensemble for Lysine Posttranslational Modifications in the rER. J. Biol. Chem. 2021, 296, 100453. [CrossRef] 